\begin{tabular}{lrrrr} 
Z E S Z Y T Y & N A U K O W E P O L I T E C H N I K I & P O Z N A N S K I E J \\
\hline Nr 77 & Organizacja i Zarządzanie & 2018
\end{tabular}

Anna ŁASZKIEWICZ*

\title{
CO-CREATING VALUE WITH THE CUSTOMERS IN MANUFACTURING COMPANIES
}

DOI: $10.21008 / \mathrm{j} .0239-9415.2018 .077 .12$

\begin{abstract}
Changes in the sphere of consumer behavior under the influence of the development and dissemination of ICTs have a significant impact on the operations of enterprises. These changes also affect the concept of value and changes taking place in this area. Over the years, "value" perceived as a set of benefits produced by the company and offered to the final recipient of the product or service has changed its character. Products began to be treated more individually, and the challenge of the marketing departments was to adapt the offer to the needs of individual clients. No longer the product, but the value associated with it became the most important.

Contemporary clients are also co-creators of value. They are involved in the process of co-creating the products and services of companies, their marketing activities, and communication. We can observe a paradigm shift in the area of business management, marketing, and interaction with the market as well as value creation.
\end{abstract}

Keywords: Co-creation, value, customer behavior, product design, design management, virtual communities

\section{INTRODUCTION}

In recent years, the issue of value has become the subject of debates and deliberations of many practitioners and researchers in this field. The value for the customer is an essential element determining the competitive position of the company (Mruk, 2010, p. 219). This concept has a multidimensional nature. Value studies cover issues such as value added, value chain, perceived value, shareholder value or value-in-use. We can talk about value from many perspectives: management, finance, marketing, service, design, innovation and product development. The mul-

\footnotetext{
${ }^{*}$ Faculty of Management, University of Lodz.
} 
tiplicity of areas in which the question of value arises affects the appearance of definitions that explain its essence from the standpoint of different paradigms, relevant to a given discipline or area. The concept of values is therefore difficult to define unequivocally, and additionally, as Mruk emphasizes, this is hampered by the subjective perspective of perceiving values by individual market players (Mruk, 2013). Changes in consumer behavior caused by, among others, global and unlimited access to information and knowledge as well as omnidirectional communication without the time and spatial constraints, have made him a conscious prosumer and in many cases the creator of products and services that meet the needs of today's buyers.

\section{BACKGROUND}

\subsection{The client as a co-creator of value in the enterprise}

In the traditional approach, the main, and expected by the enterprise, role of the client was the decision whether to purchase or refrain from it (Ramaswamy, Gouillart, 2010). The change in the perception of the client's role over the past years, both a source and effect of a stronger consumer position on the market, further strengthens the position of buyers in the enterprise-customer relationship, shifting it from the position of passive value recipient to its active co-creator.

A company that undertakes activities in the field of co-creating value with clients is "an enterprise responding to insights from the actual engagement experiences of people - customers, employees, suppliers, and other stakeholders - continuously designing and redesigning what is of value, together with them" (Ramaswamy, Gouillart, 2010). In the definition of Hoyer and Roggeveen, there is also an element related to the scope of cooperation: co-creating value through collaboration and interaction with clients may concern one or many stages of production and consumption (Roggeveen, Tiros, Grewal, 2011). Moving away from the perception of the company and its clients as elements situated on opposite sides allows a company to notice and use the potential of mutual interactions and creates the chance to develop new business opportunities (Galvagno, Dalli, 2014). Table 1 presents various definitions of value co-creation.

Co-creation with customers can occur in different areas. Agrawal and Rahman mention the following: co-production, co-innovation, co-development, co-ideation. At the same time, they emphasize that the boundaries of these areas are not clear. These activities can occur as individual initiatives or be part of a more extensive process, as in the case of joint development and implementation of innovations. We can deal here with the joint gathering of ideas, their development, the process of collective selection, testing or finally placement on the market. In turn, Galvagno 
Table 1. Various definitions of value co-creation

\begin{tabular}{|c|c|}
\hline Author & Definition \\
\hline $\begin{array}{l}\text { Groonroos \& Voima } \\
(2013)\end{array}$ & $\begin{array}{l}\text { "[...] refers to customers' creation of value-in-use where co- } \\
\text { creation is a function of interaction" }\end{array}$ \\
\hline Roser et al. (2013) & $\begin{array}{l}\text { "[...] an interactive, creative and social process between } \\
\text { stakeholders that is initiated by the firm at different stages } \\
\text { of the value creation process" }\end{array}$ \\
\hline Ind \& Coates (2013) & $\begin{array}{l}\text { "as a process that provides an opportunity for on-going } \\
\text { interaction, where the organization is willing to share its } \\
\text { world with external stakeholders and can generate in return } \\
\text { the insight that can be derived from their engagement" }\end{array}$ \\
\hline Lambert \& Enz (2012) & $\begin{array}{l}\text { "[...] as a three phase cycle comprised of (1) joint crafting } \\
\text { of value propositions, (2) value actualization (3) value } \\
\text { determination" }\end{array}$ \\
\hline Groonroos (2012) & $\begin{array}{l}\text { "[...] is a joint collaborative activity by parties involved in } \\
\text { direct interactions, aiming to contribute to the value that } \\
\text { emerges for one or both parties" }\end{array}$ \\
\hline Edvardsson et al. (2011) & $\begin{array}{l}\text { "[...] is shaped by social forces, is reproduced in social } \\
\text { structures, and can be asymmetric for the actors involved" }\end{array}$ \\
\hline $\begin{array}{l}\text { Gummeson \& Mele } \\
\text { (2010) }\end{array}$ & $\begin{array}{l}\text { "[...] is enabled by Actor } 2 \text { Actor (A2A) involvement and } \\
\text { commitment. It is a time-based process which simultaneo- } \\
\text { usly comprises parallel and sequential phases" }\end{array}$ \\
\hline Xie et al. (2008) & $\begin{array}{l}\text { "[...] Prosumption as value creation activities undertaken by } \\
\text { the consumer that result in the production of products they } \\
\text { eventually consume and that become their consumption } \\
\text { experiences" }\end{array}$ \\
\hline Zwick et al. (2008) & $\begin{array}{l}\text { "[...] as a set of organizational strategies and discursive } \\
\text { procedures aimed at reconfiguring social relations of } \\
\text { production, works through the freedom of the consumer } \\
\text { subject with the objective of encouraging and capturing the } \\
\text { know-how of this creative common" }\end{array}$ \\
\hline Payne et al. (2008) & $\begin{array}{l}\text { "[...] process involves the supplier creating superior value } \\
\text { propositions, with customers determining value when } \\
\text { a good or service is consumed" }\end{array}$ \\
\hline Wikstrom (1996) & $\begin{array}{l}\text { "[...] is company-consumer interaction (social exchange) } \\
\text { and adaptation, for the purpose of attaining added value" }\end{array}$ \\
\hline
\end{tabular}

Source: A.K. Agrawal, Z. Rahman, Roles and Resource Contributions of Customers in Value Co-creation, International Strategic Management Review, 3, 2015, 144-160. 
and Dalli (2014) emphasize that the co-creation of values can have a physical as well as a symbolic dimension; therefore they distinguish two concepts: co-creation and co-production, recognizing the need to separate these ideas. Thus, they perceive co-creation, like Vargo and Lush (2008), as a more general concept that includes various manifestations of the use of interactions between clients and companies to create value. Among them, they mention:

1. areas closely related to the role of services as a determining factor of the competitive advantage of the company, in which the cooperating customers take an active part;

2. an area that originates from the perspective of cultural research, where the client's focus is on the assumption that consumption is symbolic and cultural, in which the consumer gives the products and services a subjective meaning;

3. innovation management, customer relationship management, electronic platforms for customer engagement or platforms dedicated to open innovation.

\subsection{Using the idea of co-creation by a production company}

V. Ramaswamy and F. Gouillart (2010) present a case study and solutions implemented by Nike. "Nike Plus" is an initiative of Nike in partnership with Apple, whose task was to combine the listening habits of consumers among running consumers with the benefit of collecting and sharing data related to their physical activity. The client's involvement was based on the benefits he gained - in this case, monitoring his progress and goals set in the training plan. In addition to the monitoring function of customer sporting activity, it was also possible to compare results among other users, which increased the involvement of participants through the use of the gamification mechanism (Ramaswamy, 2009; Mccluskey, 2010). Thanks to these solutions, as the company declares, Nike has obtained the following benefits:

- knowledge resulting from observing consumer behavior using the promoted solution,

- he ability to generate new ideas in a much shorter time than traditionally,

- the opportunity to experiment with a new offer,

- direct customer contribution to shaping running preferences,

- building deeper relationships and trust within the community,

- greater attachment to the brand,

- reduction of marketing expenses due to positive word of mouth,

- sharing the risk of product/service development with a partner such as Apple. On the financial layer, the results of the campaign were as follows:

- at the end of 2007, the company obtained a $57 \%$ share in the market of running shoes in the US - it meant an improvement in the current market share by ten percentage points, i.e. an increase from $47 \%$ in 2006 to $57 \%$ in 2007 ,

- the company has sold over 1.3 million Nike + iPod Sports Kit devices and over 500,000 Nike + SportBand, 
- over 600,000 runners from 170 countries have registered on the website in one year,

- users recorded over 40 million miles during this time.

The action did not end after one year of operation. By 2008, users registered over 100 million miles, by August 2009 the number of miles increased to 150 million. Currently, this number is given in steps and amounts to 85300123718 (2016). Nike also decided to reduce its spending on traditional advertising by $55 \%$ in 2007, thus reducing the share of spending on traditional advertising to $33 \%$ of the total advertising budget. For comparison, in 1997 expenditures on conventional media accounted for $60 \%$ of the overall advertising budget.

Considering the benefits from the implemented solution from the consumers' perspective, Nike emphasizes that the actions taken were mainly a source of experience-based values for clients (Ramaswamy, 2008):

- precise monitoring and recording of achieved results,

- productivity increase,

- combining physical activity and music,

- easier goal setting,

- connecting with other users,

- access to global and local events,

- encouragement to participate in a new community of runners, trainers and coaches focused on physical activity - running.

In this project, not only "runners" created value together with the company. It also included a group of trainers and sports instructors who started using the platform for their specific initiatives. In this way, Nike could discover new areas of interaction for its clients by additionally offering monitoring and both individual and group training (Ramaswamy, Ozcan, 2014).

\section{METHODOLOGY}

The survey was conducted from August 26 to October 18, 2016 ${ }^{1}$. Due to the lack of a complete list of population elements, a targeted selection was made. Managers invited to participate in the study received links to the online survey questionnaire. The questionnaire was prepared in two language versions: Polish and English. The study was preceded by a pilot study carried out among ten managers representing companies with a different business profile and size. In the main study, 199 questionnaires were registered, including 134 with complete answers, which were subjected to further statistical analysis.

\footnotetext{
${ }^{1}$ The presented data is a part of a larger research project. A. Laszkiewicz (2018). Wspóltworzenie wartości z konsumentami $w$ środowisku wirtualnym, Wydawnictwo Uniwersytetu Łódzkiego (Łódź University Press), Łódź (in press).
} 
The sample included respondents representing enterprises whose leading business profile is service activity (over $65 \%$ of respondents), production $(19.4 \%)$ and trade $(14.9 \%)$.

\subsection{Results of the study}

Respondents were asked a question about their knowledge of the issue of cocreating value with consumers. This question contained answers, the purpose of which was to identify the level of awareness of the discussed topic. The respondents could choose a response related to the general knowledge of issues not related to business practice; an answer referring to undertaking individual actions with consumers in the area of the examined subject; and an answer in which they declared that the company in which they work co-creates value with consumers as an element of the business model. Therefore, the last of these responses can be treated as the most mature form of this kind of cooperation in an enterprise.

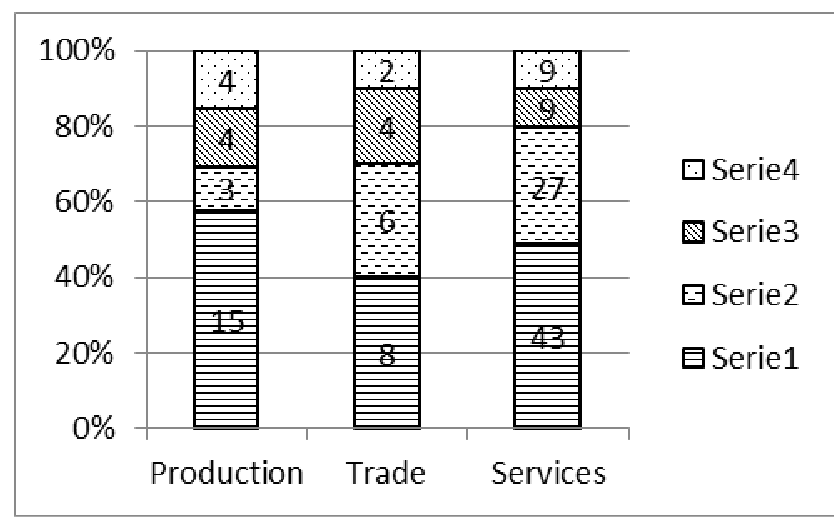

Yes, I am aware of this idea, but I did not have an

Series 1 opportunity to deal with it in business practice.

Yes. The company where I work is working with consumers in terms of value co-creation (cocreation of products, services or ideas). This kind of

Series 2 cooperation is used from time to time.

Yes. The company where I work, co-creating value with customers is part of the company's business

Series 3 model and is a constant practice.

No. I'm not aware of the issue of value co-creation

Series 4 with consumers.

Fig. 1. Knowledge of the issue of co-creating value with consumers and the profile of the company 
The largest number of respondents (43 out of 66), who are familiar with the issue of co-creating value with consumers in a virtual environment but did not deal with it in business practice, represent enterprises with a service profile. The largest number of responses (27 out of 36), indicating that the company was undertaking individual activities together with clients in the area of value creation, also came from service companies (see Fig. 1).

The study participants received a set of twelve statements regarding the benefits of implementing the idea of co-creation in the company. These benefits have been identified based on the empirical studies described in the subject literature. The respondents' task was to refer to the presented benefits with the use of a six-point scale: "I strongly disagree", "I disagree", "I do not know, it's hard to say", "I agree", "I definitely agree" and "I do not agree or disagree".

Figure 2 shows the answers for the combined intervals "I strongly agree" and "I agree" and "I strongly disagree", "I disagree".

Then, the answers "I agree" and "I strongly agree" were grouped as positive responses and the number of positive answers in the question presenting a set of twelve benefits in the division of company profiles, i.e. production, sales and service profiles, was analyzed (see Fig. 2 and 3).

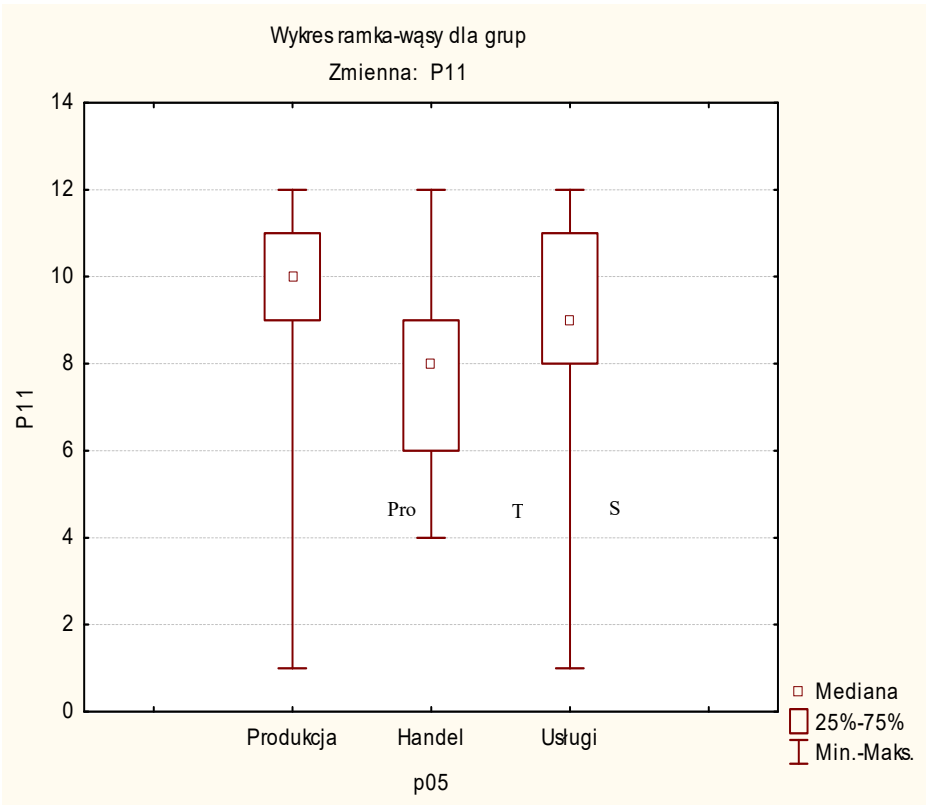

Fig. 2. Box chart of "positive" responses (I agree / strongly agree) regarding the perceived impact of co-creation of value with consumers on the market position of the company and the business profile of enterprises 


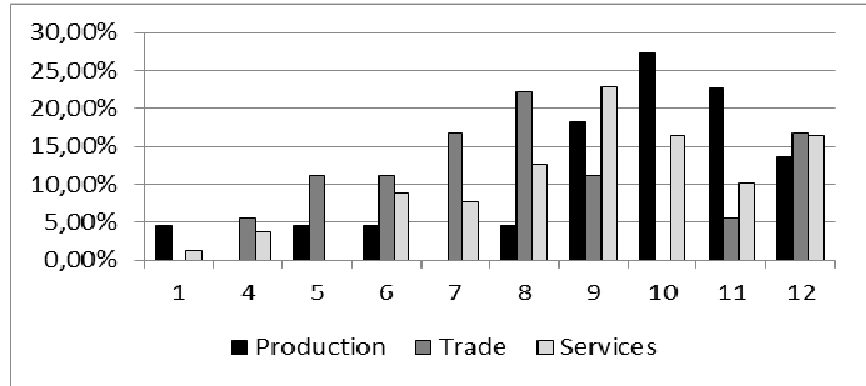

Fig. 3. The number of "positive" answers (I agree/strongly agree) regarding the perceived impact of co-creating value with consumers on the market position of the company

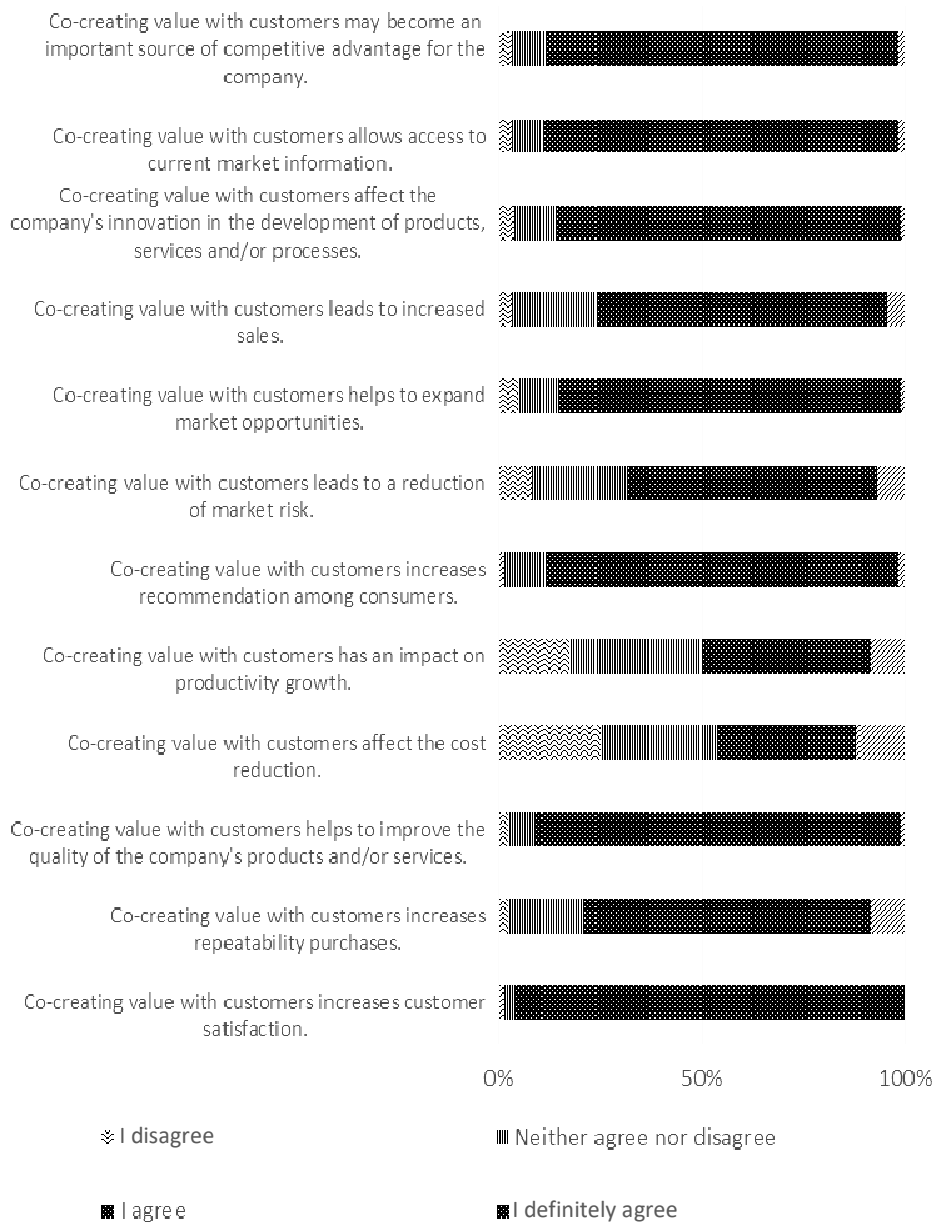

Fig. 4. Respondents' agreement/disagreement with statements regarding the benefits of implementing the idea of value co-creation in the company 
The Kruskal-Wallis test indicates that there are no significant differences between the number of positive responses for groups of respondents due to the profile of activity $(\mathrm{H}=5.690, \mathrm{p}=0.058)$. However, a small $\mathrm{p}$-value suggests that differences may be significant for more observations. The box chart shows that the number of positive responses for companies with a trade profile is lower than for service and manufacturing companies (see Fig. 4).

Representatives of enterprises participating in the survey agree in the majority of cases with the indicated benefits of using the idea of co-creating value. Of the twelve presented benefits, only two received less than $50 \%$ of positive responses. They concerned the impact of cooperation with customers on reducing costs and increasing productivity. The highest assessed were aspects related to the increase in customer satisfaction - almost $96 \%$ of positive ratings, then improvement of the quality of products and services offered by the company (almost $90 \%$ of positive responses). It is noteworthy that a large number of positive indications were among enterprises with a production profile.

\section{CONCLUSION}

Benefits resulting from the adaptation of co-creation of products and services with consumers in a virtual environment are an area that should be subjected to further in-depth analysis. It would indeed be beneficial from a cognitive point of view to carry out a study that would comprehensively analyze the market and image results of the implementation of products designed jointly with consumers. A survey conducted in 2013 concerning Muji's offer showed, among other things, that products co-created with consumers were more often perceived as innovative than projects created by the company's designers. They also achieved much higher incomes (Nishikawa, Schreier, Ogawa, 2013). Therefore, this area should be subject to further analyses and observations.

\section{LITERATURE}

Agrawal, A.K., Rahman, Z. (2015). Roles and Resource Contributions of Customers in Value Co-creation. International Strategic Management Review, 3, 144-160.

Galvagno, M., Dalli, D. (2014). Theory of value co-creation: a systematic literature review. Managing Service Quality, 24, 6, 643-683.

Laszkiewicz, A. (2018). Współtworzenie wartości z konsumentami w środowisku wirtualnym. Łódź: Wydawnictwo Uniwersytetu Łódzkiego (w druku).

Mccluskey, M. (2009). The Nike Experiment: How the Shoe Giant Unleashed the Power of Personal Metrics. Wired, June 22. 
Mruk, H. (2010). Wartość dla klienta a pozycja konkurencyjna przedsiębiorstwa. In: B. Dobiegała-Korona, T. Doligalski (red.), Zarzązanie wartościa klienta. Pomiar $i$ strategie. Warszawa: Poltext, 219.

Mruk, H., Stępień, B. (2013). Tworzenie wartości dla klienta z perspektywy konsumentów i przedsiębiorstw. Polskie Wydawnictwo Ekonomiczne.

Nishikawa, H., Schreier, M., Ogawa, S. (2013). User-generated versus designer-generated products: A performance assessment at Muji. International Journal of Research in Marketing. 30, 160-167.

Ramaswamy, V. (2008). Co-creating Value Through Customers' Experiences: The Nike Case. Strategy \& Leadership. 36, 5.

Ramaswamy, V., Gouillart, F. (2010). The Power of Co-creation, Build It with Them to Boost Growth, Productivity, and Profits. New York, Toronto, Sydney: Free Press.

Ramaswamy, V., Ozcan, K. (2014). The Co-Creation Paradigm. Stanford, California: Stanford University Press. Kindle Edition, lok. 292 z 6537.

Roggeveen, A.L., Tiros, M., Grewal, D. (2011). Understanding the co-creation effect: when does collaborating with customers provide a lift to service recovery? Journal of the Academy of Marketing Science. 40, 771-790.

Vargo, S.L., Lusch, R.F. (2008). Service-dominant logic: continuing the evolution. Journal of the Academy of Marketing Science. 36, 1, 1-10.

\section{WSPÓŁTWORZENIE Z KLIENTAMI WARTOŚCI W PRZEDSIĘBIORSTWACH PRODUKCYJNYCH}

\section{Streszczenie}

Zmiany w sferze zachowań konsumenckich pod wpływem rozwoju i upowszechniania ICT mają znaczący wpływ na działalność przedsiębiorstw. Zmiany te wpływają również na pojęcie wartości. Przestaje ona być postrzegana jako zestaw korzyści wytwarzanych i dostarczanych przez firmę. Coraz częściej udział w tym procesie mają konsumenci. Angażują się w proces współtworzenia produktów i usług firm, ich działań marketingowych i komunikacji. W artykule autorka omawia zagadnienie współtworzenia wartości z konsumentami w środowisku wirtualnym, prezentuje definicje występujące w literaturze przedmiotu, obszary zastosowań, a także przykłady adaptacji omawianego podejścia w przedsiębiorstwie produkcyjnym. W artykule zaprezentowano częściowe wyniki badania realizowanego przez autorkę wśród przedsiębiorstw w obszarze współtworzenia wartości z konsumentami.

Slowa kluczowe: współtworzenie, wartość, zachowanie klienta, projektowanie produktu, zarządzanie wzornictwem, społeczności wirtualne 